\title{
Бошко Сувајџић
}

\section{ПЕВАЧ И КУЛТУРНИ ИДЕНТИТЕТ}

\begin{abstract}
Рад говори о певачу усмених епских песама као носиоцу колективног памћења у контексту развијања културног идентитета једне заједнице. Певач је репрезент друштвених ставова заједнице, архивар колективне меморије, коју складишти у мотивске токове преузете из традиције у склопу специфичне поетике усменог спевавања. Певач је метафорични носилац усменог знања. Својом активношћу у колективу он постаје „културни тип” у процесу усмене комуникације, специфична „друштвена институција" усмене културе.
\end{abstract}

Шта чини друштвени идентитет једне заједнице? Језик? Култура? Колективна свест? Колективна подсвест? Митови? Традиција? Вера? Друштвени и политички систем? Какву улогу у томе имају епски певачи као носиоци традиције?

Питање човековог идентитета још у антици је формулисано као техника сопства или „нужност старања о себи”. Формула „бавити се собом”, која укључује и делфску максиму „упознати самога себе”, од Платонових дијалога (Алкибијад) у вези је са стицањем и чувањем знања. Ко су они који се брину о стицању и обликовању знања у античком свету? Ево шта на ово питање одговара Мишел Фуко (Michel Foucault):

„овек се не може о себи старати а да не оде код учитеља, нема старања о себи без присуства учитеља. Оно што одређује положај учитеља, за што се он стара, то је брига коју онај кога он води може да има за самог себе. За разлику од лекара или за разлику од оца породице, он се не стара за тело, не стара се за имање. За разлику од професора, не брине га да онога кога води поучи вештинама или способностима, не тежи да га научи да говори, не труди се да га научи како да однесе победу над другима, итд. Учитељ је онај који се стара о старању субјекта о самом себи, и који налази, у љубави коју 
има према свом ученику, могућност да се стара о учениковом старању о самом себи." (Фуко 2003: 83)

Питање другога у антици одговара питању о уделу средине у (само)конституисању субјекта: „Питање које се поставља гласи: каква је дакле делатност другог која је нужна да субјект сам себе конституише? Како се ова делатност другог уводи као неопходни елемент у старање о себи?" (Фуко 2003: 176)

Херменеутика субјекта нужно поред ипсеитета подразумева и алmеритеm, како то већ насловом своје књиге имплицира Пол Рикер (Paul Ricoeur): „Concmво као други од почетка наглашава да ипсеитет сопства имплицира алтеритет до тог степена да се једно не да мислити без другог, да прије једно прелази у друго, како би се рекло хегеловским језиком.” (Рикер 2004: 10)

Питање о утврђивању колективног идентитета, које се заснива на премисама о некаквом постулираном духовном, религиозном или етничком заједништву одређене скупине људи, увек је до одређене мере и питање етницитета. Другим речима, „etnicitet kao društveni identitet je kolektivan i individualan, eksternalizovan u društvenoj interakciji i internalizovan u ličnoj samoidentifikaciji” (Dženkins 2001: 27).У временима глобалног умрежавања човека у систем који га усисава и контролише, људска јединка није поштеђена искустава друштвено-политичке и културне нивелације, која се реализује према критеријумима подобности у мишљењу и расуђивању, на основу вештачки (медијски) индукованих расположења и осећања.

Када је реч о питањима сопства и алтеритета у савременим друштвеним заједницама, налазимо се у једној врсти парадоксалне ситуације. Никада није више писано, расправљано и полемисано о људским правима, о другоме, о зајемченим слободама и правима, а никада нисмо имали неслободније јединке и асоцијалнија друштва, са високим степеном отуђености и непостојањем било каквог заједничког именитеља модерног друштвеног идентитета.

Култура је несумњиво интегративни фактор друштвеног идентитета. За процењивање вредности одређене културе пресудна је категорија трајана кроз коју се дата култура једино манифестује као вредност или невредност. Однос према традицији је кључан идентификацијски код, лична карта одређене културе, која је сврстава у озбиљне националне културе у европским оквирима или не: „Како се у најширем смислу традицијом сматра све оно што се преноси из прошлости у садашњост, однос према традицији представља једну од кључних референци у обли- 
ковању конкретних идентитета - и колективних и индивидуалних, а друштвени идентитет у том духу репрезентује консензус међу живим и мртвим генерацијама." (Лајић-Михајловић 2007: 137)

Да ли традиција нужно лимитира човекове индивидуалне могућности, угрожава уметничке слободе, сужава изборе? Одговор није тако једноставан: „Дуго је владало мишљење да је традиција лимитатор слобода и да је за изражавање индивидуалности неопходан раскид са традицијом. Ипак, ближим реалности чини се процена да она само обрубљује индивидуу, да поставља услове за њене активности, утиче на детерминисање потенцијала индивидуе и њихову реализацију”. (Лајић-Михајловић 2007: 138)

Традиција се у елиотовском смислу може посматрати као низ изузетних креација наталожених у памћењу припадника једне културе, као ланац варијаната једног истог дела, медијум испољавања људског духа у времену ${ }^{1}$. Она се испољава као јединствена духовна заталасаност испод низа варијаната и обиља мотива:

„Важно је истакнути: у народном певању нема утврђених мелодија, него колико певача толико и варијаната. Значи, ту и не треба тражити ово или оно издвојено дело него истоветну природу заталасавања у свем обиљу мотива." (Настасијевић 1991: 43)

Традиција је, несумњиво, динамичка јединица:

„Ona je to u značenju koje se od opisanog razlikuje po tome što ne implicira stabilnost nego dinamičku promjenljivost skupa; po tome što se ideja neposredovanog (i eventualno usmenog) odnosa zamijenila u njemu idejom neposredno važnog i vitalnog odnosa; po tome što se odnos ne vidi u situaciji slijeda generacijâ nego u situaciji pjesnika ili pjesničke generacije koji su suočeni sa cjelinom žive prošlosti; po tome što se odnos, dosljedno, ne vidi prvenstveno kao djelovanje tradicije koja se predaje kao aktivnost onoga koji se prema tradiciji odnosi." (Petrović Sv., Poetika tradicije 2008: 77-78)

1 Образовање се за Елиота прелива преко националних граница: „Jer klasik je za njega pre svega garant zajedničkog identiteta, istorije i predanja koji prevazilaze međusobne granice. Za nacionalne klasike Eliot, s tim u skladu, nije posebno mario, pošto se 'ono veliko u svakoj književnosti ne sastoji u njenoj posebnosti, nego u njenom mestu u okviru jedne veće matrice, a tu matricu je dao Rim."' (Asman 2002: 103) 
Традиција настаје у заједничарству појединца са колективом, епохом, друштвеним регулама и језиком који је пресудно одређују. Сам ће се колектив при томе дефинисати као индекс знаменитих појединаца који су у одређеном тренутку преузели бригу о традицији. Посебно је то валидно за тип усмене културе у којој је појединац-стваралац истовремено и извођач и прималац информације коју остварује у непосредном контакту са публиком, под одређеним, строго прописаним правилима.

У усменој култури, традиција је нека врста менталне посуде у коју време сипа одређени духовни садржај, посредован старањем колектива и креацијом талентованог певача. Колектив условљава певача и условљен је њиме. Певач је репрезент друштвених ставова заједнице, архивар колективне меморије, коју складишти у мотивске токове преузете из традиције у склопу специфичне поетике усменог спевавања. Певач је носилац наслеђеног знања, уметник који свој таленат остварује у друштвеном контексту. Он је стваралац и преносилац традиције у исто време (Lord 1990 I: 38). За разлику од писане књижевности, која легитимно расписује конкурсе за нова књижевноисторијска вредновања допуштајући каткада читања занемарених, заборављених или пак несхваћених генија у новом кључу, у усменој књижевности важи правило да само ако је таленат друштвено валоризован у датом тренутку он ће бити делатан и делотворан (Самарџија 2007). У супротном, усмено дело неће проћи „превентивну цензуру" средине (Jakobson-Bogatirjov 1971: 17-31), неће бити процењено као културна чињеница вредна памћења, и у крајњој консеквенци биће предато забораву као алтернативном памћењу традиције.

Епску традицију у усменој култури чини ланац изузетних варијаната, колектив индекс знаменитих појединаца. Максимилијан Браун посве тачно закључује да се у пословима јуначког певања „између певача и песника не може повући оштра граница". Св. Петровић се одлучно залаже за превладавање границе „међу проучавањем усмене и проучавањем писане књижевности”, будући да не постоје „битне разлике међу усменим и писаним дјелом у начину на који дјело настаје”, јер је у оба случаја то „ плод индивидуалног креативног чина који се збио у неком социјалном контексту и у оквирима неке књижевне традиције” (Петровић Св., О превладавану границе 2008: 133).

Стваралачку димензију епског певача у односу према традицији својим „рачуном од пјесама” недвосмислено је устврдио још Вук Караџић. Термин „спевати пјесму” јесте у бити вуковски термин, који се не односи на мелодију:

„Zanimljivo je da stvaranje nove pesme narod naziva ispevati pesmu, ili kako je još Vuk Karadžić davno primetio - 'spjevati pjesmu', a da 
se to ne odnosi na melodiju, koju pevač 'pozajmljuje' od neke već poznate pesme, već na njen tekst." (Golemović 2005: 14-15)

Када је реч о епском певачу, у прошлости су ствари биле јасне. Знање о епском певању било је свеопште, али је умеће епског певања припадало одабранима, а певач епске песме уживао неподељен углед у јавности: „За казивање или излагање јуначке песме потребан је посебно позвани и обучени певач. Насупрот лирској народној песми, није баш свако у стању да казује или изводи јуначку песму; то је посебно умеће које је доступно само одабранима. (...) Отуда епски певач ужива велики углед; он се цени и њему се диве као богомданом уметнику. И сам певач то зна. Уметнички понос и уметничка завист нису ни епском певачу непознате ствари; неки од њих умеју да се понашају као праве звезде, а да им њихови слушаоци због тога уопште не замерају." (Браун 2004: 70)

Вук Караџић је на примеру Тешана Подруговића засновао концепт идеалног певача-казивача. Караџићеви предговори лајпцишком издању народних песама „означавају најпоузданија полазишта која је у деветнаестом веку изградила наука о усменој књижевности за решавање питања индивидуалности епских певача" (Недић 1976: 136). Ипак, ни Вуков „рачун од пјесама” није издвојио певача као индивидуалног уметника у мери у којој је он то заслуживао:

„Не би се могло рећи да Вук већ израна није уочио удео појединих певача у стварању и коначном обликовању епских песама: у предговору уз прву књигу лајпцишког издања (1823) он јасно и о томе говори - али ипак ни он, а још далеко мање његови сарадници, индивидуалном доприносу појединих певача у стварању епике нису придавали онолики значај који ми данас придајемо." (Латковић 1959: 47)

Вуково сазревање у схватању значаја и комплексне улоге певача у обликовању епске песме расло је упоредо са сазревањем његове идеје о конституисању изборника јуначких песама који ће Европи и свету представити „негдашње српско битије и име”:

„И въпреки че В. Караджич има най-голяма заслуга за събирането и публиковането на сръбската епическа традиция изобщо и на песните на слепите гуслари в частност, интересът му към институцията просешко пеене на слепците в Сърбия в основата си е интерес на човек, който по думите на Св. Матич е бил предимно 'антологичар." (Михайлова 2006: 29) 
С друге стране, управо је у Вуковим збиркама дошло до оне суштаствене промене у којој „народ није више давао сировину свога темперамента, но је већ пружао прерађену једном вишом снагом која је била зрелост његова генија" (Петровић Р. 1974: 317). Вукове заслуге у овом процесу сазревања не могу се свести на улогу „антологичара”, био он и од најфиније врсте. Караџић је много више од тога.

Након Пери-Лордове теорије формуле у савременим истраживањима епске поезије акценат се ставља на менталне процесе који посредују пренос формуле у епски „текст”. Тежиште се преноси са усменог дела на његове носиоце, певаче-извођаче:

„Савремена истраживања 'живе' усмене епике, са наглашеним захтевом за посматрањем текстуализације као динамичног процеca, донела су и преоријентацију са концепта формуле ка концепту менталног текста и епског идиолекта (Honko 1996a; Constantinescu 2006), означавајући тиме и премештање тежишта истраживачког интересовања ка носиоцима традиције као активним субјектима који ту традицију усвајају, преносе, креирају и презентирају у конкретној комуникативној ситуацији." (Ђорђевић С. 2008: 110)

Улога се усмене традиције у савремености мења, посебно са становишта експлозије средстава за масовну комуникацију, развоја интернета и електронских медија. Једна од последица глобализације јесте уклањање регионалних и локалних граница у које се фолклор ранијих епоха затварао, укидање језичких баријера и националних ознака, разобручавање клишеа, рашчауреност садржаја. (Бокова: 66) Моћни процеси уједначавања или нивелације који су са становишта фолклора не само легитимни него и неопходни у епохама модерног и постмодерног друштва уврштавају фолклорне премисе у токове и правце светске глобализације и обрасце ноторног унификовања вредности:

„Едно мощно движене на унифициране начините на живот и необходимостта от идентификатори за оцеляване в търсене на различни видове 'тъждественост'-идентичност отного извеждат на преден план проблема за фолклора и съвременните му хипостази.' (Бокова 1993: 64)

Несумњиво је да у модерним друштвима „информативни тип културе” односи превагу над „фолклорним типом културе”. Не само то: информативна култура преузима искуства фолклорне културе на једном технички софистициранијем нивоу. Агресивни „ријалити” програми 
који нас опседају теже да на медијски атрактивном нивоу нивелишу глобално људско искуство и поврате процесу комуникације међу људима првотни легитимитет, изравну непосредност и несебичну узајамност. Све то је претходно медиј морао одузети фолклору као комуникацијском чину. У медијском концепту „ријалити” шоу програма хотимично се хоће индуковати фолклорна комуникативна ситуација. Неопходна се улога механичког посредника (медиј, слика, звук, интернет) маскира или минимизира. Медиј се служи мимикријом, камуфлира се.

У „ријалити” шоу-програмима на делу је смишљено провоцирање човекове радозналости које се покушава остварити приземним опонашањем живота, непримереном колоквијалношћу и опсценом простотом. Тријумфују баналност и кич као носиоци квазиуметничких културних садржаја. Девијација људскости, која је посредством камере видљива и тиме доступна свачијем оку, врши се у име (изгубљене) људскости. Она је узрокована покушајима надомештавања непосредности и блискости коју индукује жива комуникација међу људима. Оваквим шоу-програмима девастирају се и човек и медиј. Медиј у покушају да досегне људску (у бити усмену) животност и непосредност, човек у покушају да се медијски препакује и прода као комерцијално прихватљив производ. „Ријалити” шоу програм представља врхунац глобалне медијске хипостазе празнине, бастард свеопште и (не)достижне пројекције жеља милиона, форматизован у медијско-маркетиншки избрушеном облику. Он човеку даје кич уместо илузије. Даје му лажну стварност уместо привида. У бити, даје му све што има зато што не поседује ништа.

Епско певање је са културно-историјског, функционалног и семантичког становишта тесно повезано са инструменталним извођењем. Најчешће је епски певач и инструментални извођач-гуслар (Захариева 1987: 189). Подразумева се да је извођач овладао древном вештином ударања у гусле. Реч је о врло архаичном начину извођења који подразумева посебну „угодбу” и специфичан „гласоред”: „Због тога што гуслари и данас певају и ударају уз гусле својим нарочитим размацима, који су им остали, по свој прилици, још од старих словенских гласореда, не може се рећи, да гуслар пева у дур- или мол гласореду, јер ни једна од данашњих дурили мол-скала није исто, што гуслареви гласореди, за то, што ни једна од данашњих скала нема те размаке." (Каракашевић 1898: 17)

Када је реч о епском певању уз гусле данас, несумњиво је да је дошло до изванредно великих промена у начину и контексту извођења, peпертоару, сценском наступу, начину комуникације са публиком, као и у публици самој (Големовић 2008: 56). Наглашено свечани чин извођења епске песме, позивање на озбиљност извођачке ситуације и неопходност 
сталног оверавања проходности комуникативног кода у савременом фолклору указују на потребу за културном верификацијом, за ритуалном идентификацијом извођача са традицијом: „Доживљавање гуслања као 'свечаности' указује и на потребу за очувањем традиције према којој се гаји поштовање, а чин извођења постаје један од кохезионих фактора групе са заједничком културном традицијом, при чему се и наизглед неритуални контекст интерактивном комуникацијом онога ко песму изводи и слушалаца, уз повремено истакнут емпатијски доживљај садржаја песме (Ђе неки одма чак старии, луди старији, почети одма сузе), ритуализује и одваја од 'профаног' (уп. Reichl 2003; аутор трагање за етничким и културним идентитетом види као важан чинилац извођења усмене епике)." (Ђорђевић С. 2008: 114).

Певање уз гусле у прошлости је имало снажне друштвено-политичке и националне импликације. У романтичарској епоси на гусле је положен темељ поретка српске националне заједнице. Гусле су схваћене као венац духовног узрастања српског народа. Код Вишњића једнако као код Његоша. Код Његоша једнако као код Лазе Костића:

„То епско доба, које несумњиво има дугу историју и засеца у дубоку прошлост, окружује и испуњује Његошево детињство и прву младост. Ту несумњиво лежи и корен његових врло раних песничких покушаја. Зна се да је радо и добро певао уз гусле. Вук Врчевић износи како је код владике Петра I у време Његошева првог школовања на Цетињу (1824-25) било десетак ђака из разних крајева Црне Горе који су се у манастиру учили писмености, и нешто момака који су се бринули о стоци и њивама манастирским, како је увече уз ватру скоро редовна забава било гуслање, причање предања и анегдота." (Меденица 1975: 141)

Шта су представљале гусле у прошлости? Друштвено институционализовани културни артефакт који интегрише заједницу, спаја је са коренима, даје јој смисао постојања? Историјски подсетник, којим се обележавају најдраматичнији тренуци у животу заједнице и акцентују најважнији догађаји? Усмени уџбеник чојства и јунаштва, у коме се из страшних искушења извлаче поуке за будућност како би се будућност сачувала од искушења?

Шта гусле представљају данас у српском друштву? Синоним за одсуство сваког смисла за политички прагматизам и друштвену реалност; алиби за национално (само)изгнанство из европских токова у освит трећег миленијума, за време у коме смо као народ били изопштени из европских процеса и из савремених друштвених заједница света, или 
пак поштовања достојан артефакт прошлости, на коме почива библија српског хероизма, српска класика?

Према Чоловићу, може се говорити и о политичко-симболичкој (зло)употреби овог инструмента, која траје последња два столећа:

„Tokom vremena sadržina guslarskih pesama, uloga guslara i simboličko značenje gusala i guslara menjali su se u zavisnosti od promene istorijskog i političkog konteksta. Te promene odnosile su se najpre na mesto koje je ovaj instrument dobijao u političkom i kulturnom životu u pojedinim balkanskim zemljama, u njihovim medijima, u školi, u vojsci, zatim, odnosile su se te promene i na ciljeve politike kojima su gusle služile. Ali, sve do danas gusle su sačuvale mesto u politici simbola nekoliko balkanskih zemalja." (Čolović 2008: 134)

У бити, гусларска се традиција данас налази на периферији српског културног простора. Али је и културни простор српског народа померен ка периферији културног простора света. Промена етнокултурне позиције епског певача огледа се у тенденциозном потискивању гусларске извођачке праксе на маргину друштвених збивања. Мења се не само концепт извођења и извођача већ и концепт слушаоца.

У савременој гусларској извођачкој пракси уочљиве су промене у репертоару, сценском наступу, стилу, тематици, али и у версификацији, посебно када је реч о употреби риме у структури трохејског епског десетерца. „Савремени” десетерац је углавном римовани десетерац:

„Десетерачке пјесме, новијег типа, су углавном римоване. Ако рима тече лако, то јест ако се њој ријечи природно слажу, онда је занимљива и драга слушаоцу. Недостатак већине, таквих пјесама је у сиромаштву садржаја, у слабо израженој фабули. (...) Истина, да има добрих пјесама римованог десетерца и осмерца и можемо их сврстати у антологијске пјесме, а посебно оне које прате историјске догађаје као већина пјесама, Радована Бећировића у којима има историје колико и поезије." (Алексић 2005: 61)

У савременом извођењу уочавају се, уз ритмичке, и одређене мелодијске измене (Golemović 2005: 14). Мењају се и социјалне компетенције извођача у светлу односа са другим његовим социјалним компетенцијама: „Будући да се описане ситуације углавном односе на гуслање у оквирима познатог, 'свог' колектива, где извођач дели заједнички културни и локални микроидентитет са својим слушаоцима, логично је очекивати да се процена извођачке компетенције не може до краја одвојити од 
става према другим његовим социјалним улогама (статус у породици, локалној средини и сл).” (Ђорђевић С. 2008: 115)

Када је реч о савременој епској поезији, гусле се хотимично покушавају представити као симбол подела етничких заједница на простору бивше Југославије, синоним за два неспојива система вредности. Политички је индуковано и друштвено институционализовано потирање моћне линије искуственог талога традиције, чији је заступник био епски певач као носилац колективног памћења, зарад тзв. европских вредности:

„Промене у односу према гуслама које произлазе из националних или верских 'различитости', очигледно је да представљају тековину новог времена. Тако су од нечега што исказује једнакост, гусле постале синоним различитости, а тим и поделе овдашњег становништва. Подела која се на просторима некадашње Југославије после њеног распада деведесетих година јавила на националном и верском плану, учинила је да се, генерално гледано, православци поистовете с гуслама, муслимани са 'оријенталном' тамбуром, најчешће сазом као њеном градском варијантом, а католици, као што је то већ поменуто, с тамбурицом панонског типа." (Големовић 2008: 53)

Шта не ваља са гуслама, те их се малтене сви народи у бившој Југославији, а посебно они који су гусларску традицију најистрајније неговали, експлицитно одричу? Можда то што су гусле симбол сличности, узајамних веза, заједничке традиције, укорењености у исту матрицу која се сада по сваку цену хоће раскоренити, разбаштинити, прогласити непожељном, ретроградном и - туђом. Гусле, као симбол „мрачне националистичке прошлости на Балкану", по правилу припадају другоме:

„Razlog što danas graditelji nacionalnih identiteta na Balkanu izbegavaju da u svojim projektima daju mesto guslama nije samo u njihovoj današnjoj, u poslednjim ratovima stečenoj, ozloglašenosti. Nema sumnje da se danas u izboru simbola balkanskih nacija pre svega teži tome da se izbegne podudarnost sa simbolikom koju rabe susedi, bez obzira o kakvoj je simbolici reč. U očima današnjih balkanskih nacionalnih ideologa gusle imaju najpre tu lošu stranu što podsećaju na sličnost između balkanskih naroda, sličnost koju vođe tih naroda teško podnose. Budući da su se tokom poslednjih godina Srbi vezali za gusle, onda se Bošnjacima i Hrvatima preporučuje da taj instrument zaborave i da u muzičkoj baštini Balkana ili čak na nekom drugom mestu, potraže kakav instrument koji je još ostao, ako se tako može reći, slobodan od simboličke službe." (Čolović 2008: 166-167) 
Ако се гусле у Србији потискују и потцењују као нешто анахроно и ретроградно, онда је у „колевци” ове музичке традиције, у Црној Гори, стање још горе. Димитрије Големовић у том смислу износи више него драгоцено лично искуство са једне трибине у Црној Гори:

„На трибини 'Фолклор у Црној Гори данас' о гуслама и њиховом месту у нашој култури говорио сам афирмативно, међутим, у томе сам био усамљен, а моје излагање било је пропраћено низом негативних квалификација на рачун гусала и певања уз гусле. То је ишло чак дотле да гусле као симбол примитивизма, али, зачудо и српства, треба 'пребити надвоје, јер шире шунд', а уз то да се с њима, таквим какве јесу, не може 'ући у Европу'. Неколицина дискутаната том приликом чак се оградила од савремене гусларске праксе, па чак и од гуслара који је гаје, уз речи: 'Они ваши', што је звучало трагикомично, будући да је већина гуслара на које су дискутанти мислили, иако углавном живи у Србији, рођена у Црној Гори." (Големовић 2008: 50)

И у Србији и у Црној Гори гусле постају вештачка разделница између европских и традиционалних вредности. Као да се заборавио мудар наук Момчила Настасијевића формулисан у његовом у програмском есеју За матерғу мелодију: „Ништа општечовечанске вредности није постало случајним укрштањем споља. Кобна је обмана посреди. Свима припадне само ко је кореном дубоко продро у родно тле. Јер опитечовечанско у уметности колико је иветом изнад толико је кореном испод националоног." (Настасијевић 1991: 44) У Србији се стога као аутохтони национални инструмент који служи за преношење традиције жели наметнути труба, у Црној Гори пак тамбура:

„Она је у толикој мери постала доминантна у свим музичким/ културним збивањима, да би неко ко није упознат са ситуацијом на плану традиционалне музике, помислио да је тако било и у прошлости, о чему у свом чланку исцрпно говори етномузиколог Јована Папан. Као разлог за поменуто ширење тамбуре Јована Папан истиче како 'жељу' Црне Горе да се 'отвори' Европи, а самим тим 'огради' од гусала, тако и тенденцију приближавања Црне Горе Босни и Херцеговини, па и Хрватској, државама сличне историје и 'судбине', државама које тамбурицу 'држе за националне симболе"' (Големовић 2008: 52-53)

Мора се признати да сам репертоар појединих савремених гуслара доприноси атрофирању традиције и изобличавању изворних епских 
вредности ${ }^{2}$ на пиратским самоиздат носачима звука који шљаште од кича и шунда, од крупних речи и порука, актуелних тема и најприземнијег политичког ангажмана³.

Каква је била улога гуслара у прошлости? Несумњиво важна. Гуслар је у прошлости имао улогу митског певача, задуженог да се брине о епско-историјском памћењу заједнице. Сама инструментална пратња није била пука декоративна појава. Инструмент је представљао суштаствени део извођачког умећа, израз префињене стваралачке креације епског певача:

„Самият смисъл на инструменталното присъствие - като част от епическия акт, като вид инструмент и инструментален тембър, като музика, с най-съществените си черти се включва в тоя комплекс на обособено и ярко изразено различие спрямо останалите обредно-художествени практики във фолклорната култура, свързани с пеене и инструмент." (Захариева 1987: 189)

Свака је песма била непоновљива извођачка креација, и у тој креацији певач се трудио да удешава боју и звук гусала према боји и звуку свога гласа:

„Пјевање уз гусле је у ствари узвишено рецитовање. Гуслар треба да прилагоди глас и звук гусала, а то је тренутак кад ријеч треба да оживи и имагинарне слике претвори у сталне." (Алексић 2008: 28) Гуслари су се разликовали и према томе како извијају своје мелодије, кроз коју школу пролазе, којим гласом певају: „Гуслари певају природним гласом и нешколованом техником. Мелодија није никада стална. Она је непрекидна импровизација према изабраном ритмичком клишеу. Сваки гуслар има сопствени клише певања, који је наследио од својих предака или га је сам изградио. Неки гуслари певају више мелодија, а и једну мелодију на више начина. Мелодије појединих гуслара увек се чини да су нове." (Радовановић 2000: 61)

2 Када говоримо о деепизацији као значајном поетичком чиниоцу обликовања репертоара епских певача данас, треба имати у виду да је и у прошлости репертоар слепих путујућих певача просјака био са становишта социјалних компетенција изразито функционализован, сачињен више од религиозних песама неголи од јуначких (Михайлова 2006: 14).

3 Реч је о новијим песмама које обрађују заметна дешавања из последњих ратних година, типа: Ој, Србине, проклета нацијо; Романијо, горо од јунака; Срби, браћо, да запјевам и ја, или Имам брата, јелика га крије, и сл. 
Какав је друштвени утицај гуслара у савременом српском друштву? Гуслари у савременом друштву губе прерогативе друштвене моћи и утицаја, које су у прошлости поседовали. У анегдотама о односу устаничких војвода према Филипу Вишњићу готово да се може опипати друштвена моћ која проистиче из симболичке везе певача Устанка и његових јунака: „У осврту на Вишњићеву биографију могуће је запазити још два, за ово разматрање изузетно значајна детаља: довођење у везу овог певача и јунака о којима пева, и везивање Вишњића и значајних фигура ондашњег политичког живота. Оба мотива заправо означавају везу певача са фигурама моћи. То је истинска (политичка) моћ, када је реч о Вишњићевим савременицима са којима га анегдоте повезују, односно симболичка моћ и потенцијал ауторитарности јунака из традиције о којима пева." (Ђорђевић С. 2009: 60)

Према Ивану Чоловићу, последње ратне године на Балкану представљају пример политичке злоупотребе гусала као симболичког оваплоћења легитимности народне власти:

„Gusle, kao narodni instrument, pre svega simbolizuju vox populi i njihova osnovna funkcija u političkoj komunikaciji sastoji se u tome da svojim autoritetom jamče da oni koji vrše vlast ili žele da je preuzmu to čine u ime naroda. Budući da se u novijoj istoriji svaka vlast predstavlja kao vlast $\mathrm{u}$ ime naroda, gusle su se našle u situaciji da svedoče o narodnom legitimitetu najrazličitijih režima i ideologija koji su se smenjivali tokom protekla dva veka u pojedinim balkanskim zemljama." (Čolović 2008: 142-143)

Крупне су промене и у сценском наступу гуслара, о чему врло инспиративно сведочи Димитрије Големовић:

„Наступ гуслара скоро као по правилу био је театралан, а нарочито његов крај, када је по завршеном певању, скоро сваки од извођача устао, држећи инструмент обема рукама, као неку бебу - прво испред себе, а онда и подижући га увис, за чим је следио 'дубоки' наклон упућен публици (!). Оно што је занимљиво, а што, зачудо, показује својеврстан игнорантски однос према публици, јесте веома слободно понашање гуслара на сцени у време када не наступају, што кулминира напуштањем сцене пре завршетка концерта. (...) Поштовање према гуслама и оном што оне представљају, на жалост, нестало је с временима која су за нама, уступајући место новим обичајима и вредностима." (Големовић 2008: 58) 
Посебан феномен у савременом друштву представљају покушаји политичке злоупотребе гусала. Покушаји контролисања певачког репертоара видљиви су још у доба књаза Милоша:

„Књаз Милош је волео гусле, и сам је гуслао, окупљао је гусларе око себе: старца Милију, већ поменутог Ђура Милутиновог Црногорца и друге, али није дозвољавао да се певају песме о Првом српском устанку, а поготову оне у којима се помиње Карађорђе. Уношење таквих песама у Србију било је строго кажњиво." (Добричанин 2007: 43) О овој појави је писао, у другом контексту, и Матија Мурко (Murko 1951: 41).

Враћамо се на почетак разговора. Техника сопства у старој Грчкој у вези је са стицањем и чувањем знања. Бавити се собом и старати се о себи не може човек који се не бави сопственом традицијом и који се не стара за сопствени културни идентитет. У том смислу, певач у функцији институционализованог и колективног памћења славне прошлости више не постоји јер у савременом друштву, у измењеним околностима, и са измењеним етнокултурним функцијама, потреба за њим више не постоји. Али постоји једна друга потреба: да се усмена епска реч, која је у темељу српског националног и културног идентитета, не девалвира у сулудом настојању да пошто-пото преваспитамо сами себе и постанемо нешто што као народ никад нисмо били нити смо могли да будемо. Стална настојања да се потре српска традиција под изговором да се у њој крије заметак националистичких, што ће рећи ирационалних и опасних примисли, представљају еклатантан пример злоупотребе „баналног национализма” (Bilig 2009). Ни сви идеолошки цензори савременог српског друштва, који будно мотре динамику његовог одрицања од сопствене традиције и културе, не могу затомити свежину и виталност усмене епске традиције, као и плодотворни значај који је она имала у обликовању српског културног идентитета.

\section{ЛИТЕРАТУРА}

Алексић 2005: Славко Алексић, Ђорђије Копривица, Гусле на крилима народног и Његочевог сочиненија, Београд.

Asman 2002: Alaida Asman, Rad na nacionalnom pamćenju. Kratka istorija nemačke ideje obrazovanja, prevela s nemačkog Aleksandra Bajazetov-Vučen, Biblioteka XX vek, 124, ur. Ivan Čolović, Beograd: Čigoja štampa. 
Bilig 2009: Majkl Bilig, Banalni nacionalizam, preveo s engleskog Veselin Kostić, Biblioteka „XX vek”, ur. Ivan Čolović, Beograd: Idea.

Бокова 1993: Ирена Бокова, Фолклор и начионална идентичност, Български фолклор, кн. 4, София.

Браун 2004: Максимилијан Браун, Српскохрватска јуначка песма, Едиција „Студије о Србима”, превео с немачког Томислав Бекић, Београд: Завод за уџбенике и наставна средства; Вукова задужбина. Нови Сад: Матица српска.

Golemović 2005: Dimitrije O. Golemović, Etnomuzikološki ogledi, Biblioteka „XX vek” 95, ur. Ivan Čolović, drugo izdanje, Beograd: Idea.

Големовић 2008: Димитрије О. Големовић, Пјеване уз гусле, Београд.

Добричанин 2007: Мирко Добричанин, Сјај гусала, Београд: Интерпрес.

Ђорђевић С. 2008: Смиљана Ђорђевић, Између носталгије и ироније: фигура гуслара и извођачка ситуачија, Научни састанак слависта у Вукове дане, књ. 37/2, Београд: Међународни славистички центар.

Ђорђевић С. 2009: Смиљана Ђорђевић, Епски певач као јунак - механизми хероизације, Научни састанак слависта у Вукове дане, књ. 38/2, Београд: Међународни славистички центар.

Jakobson-Bogatirjov 1971: Roman Jakobson, Pjotr Bogatirjov, „Folklor kao naročit oblik stvaralaštva” (1929), preveo Stjepan Stepanov, u: Usmena književnost. Izbor studija i ogleda, prir M. Bošković-Stulli, Zagreb: Školska knjiga.

Каракашевић: 1898: Владимир Каракашевић, Гусле и гуслари. Прилог уз културно-историјску расправу 'Музичка уметност у Срба', Летопис Матице српске, књ. 195, св. 3, Нови Сад, 1-39.

Лајић-Михајловић 2007: Данка Лајић-Михајловић, Гуслар: индивидуални идентитет и традиција, Музикологија, бр. 7, Београд.

Латковић 1959: Видо Латковић, Вуков „рачун од јуначких песама”, Ковчежић. Прилози и грађа о Доситеју и Вуку, ур. Ђуро Гавела, књ. друга, Београд: Вуков и Доситејев музеј.

Lord 1990 (1): Albert B. Lord, Pevač priča (1). Teorija, prevela sa engleskog Slobodanka Glišić, Biblioteka „XX vek” 71/1, ur. Ivan Čolović, Beograd: Idea.

Меденица 1975: Радосав Меденица, Наша народна епика и юени твории, Цетиње.

Михайлова 2006: Катя Михайлова, Странстващият сляп певеи просяк във фолклорната култура на славяните, София: Българска академия на науките, Институт за фолклор.

Murko 1951: Matija Murko, Tragom srpsko-hrvatske narodne epike, Djela Jugoslavenske akademije znanosti i umjetnosti, knjiga 41, Zagreb. 
Настасијевић 1991: Момчило Настасијевић, „За матерњу мелодију” (1929), у: Есеји, белешке, мисли, прир. Новица Петковић, Сабрана дела Момчила Настасијевића, у редакцији Новице Петковића, књ. 4, Горњи Милановац: Дечје новине; Београд: Српска књижевна задруга, 38-46.

Недић 1976: Владан Недић, О усменом песништву, прир. Мирослав Пантић, Београд: Српска књижевна задруга.

Петровић Р. 1974: Растко Петровић, „Младићство народног генија” (1924), у: Есеји и члании, Дела Растка Петровића, књ. VI, прир. Јован Христић, Београд: НОЛИТ, 313-370.

Петровић Св. О превладавању границе 2008: Св. Петровић, „О превладавању границе међу проучавањем усмене и проучавањем писане књижевности" (1975), y: Svetozar Petrović, Pojmovi i čitanja, Napomene i bibliografske reference uz tekst Dejan Ilić, Novi Sad: Srpska akademija nauka i umetnosti-Ogranak; Beograd: Fabrika knjiga, 2008, 133-149.

Petrović Sv. Poetika tradicije 2008: Svetozar Petrović, „Poetika tradicije: 'utjecaj narodne poezije' u jednoj pregršti renesansnih tekstova" (1972), u: Svetozar Petrović, Pojmovi i čitanja, Napomene i bibliografske reference uz tekst Dejan Ilić, Novi Sad: Srpska akademija nauka i umetnosti-Ogranak; Beograd: Fabrika knjiga, 72-86.

Радовановић 2000: Лазар Ћ. Радовановић, Епска поезија и гусле, Београд: Зенит.

Рикер 2004: Пол Рикер, Сопство као други, Философска библиотека Aletheia, 25, ур. Богољуб Шијаковић, с француског превео Спасоје Ђузулан, Никшић: „Јасен”; Београд: Службени лист СЦГ.

Самарџија 2007: Снежана Самарџија, Увод у усмену књижевност, Београд: Народна књига, Алфа.

Фуко 2003: Мишел Фуко, Херменеутика субјекта. Предавања на Колеж де Франсу 1981-1982, прир. Фредерик Грос под управом Франсоа Евалда и Алесандра Фонтане, с француског превели Милица Козић и Бранко Ракић, Нови Сад: Светови.

Čolović 2008: Ivan Čolović, „Sve te gusle. Prilog proučavanju političke istorije jednog muzičkog instrumenta", u: Balkan, teror kulture. Ogledi o političkoj antropologiji, 2, Beograd. Biblioteka XX vek; Knjižara Krug.

Dženkins 2001: Ričard Dženkins, Etnicitet u novom ključu. Argumenti i ispitivanja, sa engleskog prevela Ivana Spasić, Biblioteka „XX vek”, knj. 117, Beograd: Čigoja štampa, 2001. 
Boško Suvajdžić

\section{A SINGER AND A CULTURAL IDENTITY}

\section{Summary}

The paper focuses on a singer of oral epic songs who is a carrier of collective memory in the context of the development of a cultural identity of a community. When it comes to epic songs today, one could undoubtedly say that highly significant changes affect the manner and the context in which they are performed, their repertoire, their performance on stage, the way they communicate with the audience and the members of the audience themselves. The change in the ethnocultural position of a singer of oral epic songs in the contemporary Serbian society is reflected in the deliberate relegation of the practice of gusle-playing to the margins of society. 